\title{
Clinical trials in acute upper gastro-intestinal bleeding
}

\author{
M.J.S. LANGMAN \\ University Department of Therapeutics City Hospital, Nottingham (England)
}

\section{Valeur des essais cliniques dans les hémorragies digestives hautes}

Comparative studies have confirmed that endoscopic examination is superior to barium radiology in the diagnosis of acute upper gastrointestinal bleeding. In general more diagnoses are made, and the overall proportions which are correct are also greater. If management is aided then logically: a) mortality rates should fall and/or, b) operation rates should change and/or length of hospital stay should be reduced. Available data do not suggest that any such gains have occurred. Thus in a recently completed study of 1037 patients who were randomly allocated to investigation by endoscopy $(\mathrm{E})$ or barium meal radiology $(R)$ by conventional double-contrast techniques, mortality rates ( $\mathrm{E} 8,4 \%$ and $\mathrm{R} 7,6 \%$ ) operation rates ( $\mathrm{E} 18,1 \%$ and $\mathrm{R} 18,2 \%$ ) as well as average length of hospital stay were virtually identical [1].

If overall advantages cannot be discerned then specific benefits in individual subgroups should be sought. Two groups of lesions which tend to be missed by radiological investigation are acute mucosal lesions and oesophageal varices. Acute mucosal lesions seem to vary considerably in the frequency with which they are found endoscopically, and so far no clear explanation is available for (say) the high prevalence in Glasgow, Scotland and in the U.S.A. in New York and Detroit, but much lower figures in Scotland in Aberdeen and in the U.S.A. in Portland and Houston [2]. Though some superficial lesions, particularly if generalised, bleed severely, the great majority are self-limiting, and do not present a further hazard to health. Whether they are diagnosed positively or their presence inferred from negative radiology may therefore matter little.

Though oesophageal varices may be detected radiologically, diagnostic precision is less than with endoscopy, and endoscopy offers the important advantage that bleeding which is occurring from varices or from other associated lesions can be distinguished, management of each differing radically. In areas where hepatic cirrhosis is common endoscopy may therefore
Adress for reprint : M.J.S. LANGMAN, University Department of Therapeutics, City Hospital, Nottingham (England).
Key-words : clinical trials, endoscopy, upper GI bleeding.

Mots-clés : endoscopie, essais thérapeutiques, hémorragies digestives. 
confer advantages in the management of haematemesis and melaena, though the extent of any gain is unclear.

The mortality rate in bleeding chronic ulcer is high in elderly people, about a quarter of patients aged over 70 years dying. Examination of this mortality suggests that deaths can be divided into three broad groups : a) those where coincident severe disease such as heart failure or cancer of the lung inhibited active management; b) deaths following operation, usually due to complications such as pneumonia and cardiovascular disease ; and c) some, usually, a few, deaths ascribed to continued bleeding.

Conventional wisdom suggests that early operative intervention is beneficial, there are no controlled trials, and an equally sound case can be made for suggesting that an aggressive early operative policy replaces deaths from bleeding by post-operative deaths. Comparisons of results in our hospitals, one of which had a more active interventionist policy than the other whilst admitting patients with bleeding of equivalent severity from the same area, showed no evidence of benefit in terms of a reduced mortality rate [3]. In the same hospitals over a five year period the operation rate for bleeding peptic ulcer, gastric or duodenal, has fallen from about a third to a fifth with no change in overall mortality.

If an operative policy is to be avoided then two problems remain; can effective means of stemming continued ulcer haemorrhage be introduced, and is the risk of further bleeding so high that continued prophylaxis is necessary?

A variety of methods of stemming bleeding have been devised. So far there is no convincing evidence that drug treatment helps. Cimetidine seems to have no specific advantages; and though antifibrinolysis has proved promising in some hands, confirmation of its value is needed.

Endoscopic methods have included the use of cyanoacrylate tissue glues, electrocoagulation and laser application. Theoretical promise has not been matched by practical demonstration of value. This may not reflect actual lack of value so much as difficulty in showing a change in any individual measure indicating success or failure.
The choice of measures logically includes changes in death rates, operation rates and transfusion requirements. If mortality rates are chosen as the prime indicator then the triallist has to recognise the difficulties which prevail in trying to show a fall in a relatively low mortality rate. Taken overall the mortality rate associated with haematemesis and melaena is about ten per cent. A halving of this mortality, an impressive achievement, would require the admission of a very large number of cases to detect such an improvement. Table $1 \mathrm{~A}$ shows the sample sizes required in treated and control groups to detect a fall in mortality rate form 10 to $5 \%$ and from 15 to $5 \%$. A modest level of significance requires large numbers, and these are clearly excessive if the power of the test, that is its chances of detecting a difference if truly present, are to be adequate. Thus to have four chances in five of detecting a halving of mortality from 10 to $5 \%$, over a thousand cases are needed, whilst reduction to a half and half chance still needs over 500 cases. In this context the triallist is in a worse position than the cardiologist who in assessing the value of drugs in myocardial infarction starts from a mortality rate of about twenty per cent, and still has considerable difficulty in obtaining reliable results.

TABLE 1

SAMPLE SIZES NEEDED TO DETECT CHANGES IN PROPORTION RESPONSES

AT A GIVEN LEVEL OF SIGNIFICANCE AND POWER [4]

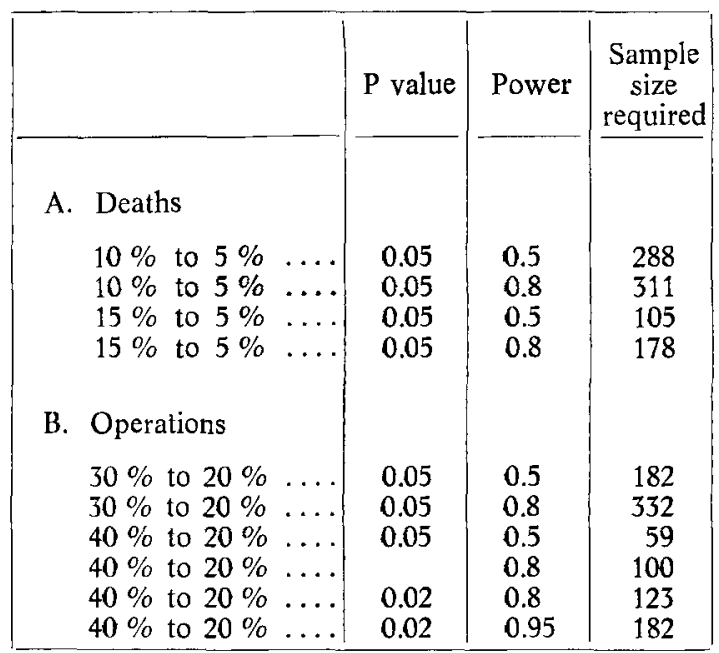


Concentration on an individual subgroup, such as gastric ulcers, with a higher mortality gives greater scope for benefit, but has the disadvantage that only a minor (if sizeable) proportion of cases are eligible for the trial, and so the time for completion is lengthened.

Recourse to operation is another possible index, but here there is the possible confounding factor that the indications for operation are based more upon belief of what is useful than upon knowledge. The proportions needing operations probably lie between a fifth and a third in duodenal and gastric ulcer, and if firm criteria could be defined, reduction in operation rates could be useful. However, the likely size of patient series still remains high. Thus Table $1 \mathrm{~B}$ shows that to detect reliably nineteen times out of twenty), a fall in operation rate from 40 to $20 \%$ at a significance level of one in fifty would require 360 cases.

A remaining criterion is transfusion requirement. This is affected in part by the severity of blood loss before treatment, and in part by the clinician's judgement of need, which may differ from actual need. It is probably the weakest criterion of all, yet related most directly to what we wish to measure.

Given these problems, it is unsurprising that few successful clinical trials in haematemesis and melaena have been conducted, and the majority of data consist of small numbers giving inconclusive results. Such findings would not be acceptable in, say, the assessment of secondary prevention of myocardial infraction, should they be so in examining the value of treatments for haematemesis and melaena?

\section{REFERENCES}

1. DRONFIELD M.W. VELLACOTT K.D., ATKINSON M., LANGMAN M.J.S. - Comparison of endoscopic and radiological investigation of patients with acute upper gastrointestinal bleeding. Gut., 1980, 21, A 897.

2. WATKINSON G. - Epidemiological aspects of peptic ulcer, in Topics in Gastroenterology 7.

La supériorité de l'endoscopie sur la radiologie dans le diagnostic des hémorragies digestives hautes a été confirmée par des études comparatives. Un nombre plus élevé de diagnostics est posé, et la proportion de diagnostics exacts est également plus élevée. Si le traitement est ainsi précisé, alors logiquement : a) le taux de mortalité devrait baisser et ou b) le pourcentage d'opérations devrait changer, et la durée d'hospitalisation devrait être réduite. Les données disponibles ne montrent pas de telles modifications. Ainsi dans une étude récente de 1037 patients investigués de façon randomisée, par endoscopie ou radiologie en double contraste, la mortalité $(8,4 \%$ et $7,6 \%)$, la proportion d'interventions $(18,1 \%$ et $18,2 \%)$, de même que la durée d'hospitalisation étaient quasiment identiques.
S.C. Truelove and C.P. Willoughby, Eds. Blackwell Scientific Publications, 1979.

3. DRONFIELD M.W., ATKINSON M., LANGMAN M.J.S. - Effect of different operation policies on mortality from bleeding peptic ulcer. Lancet, 1979, 1,1126

4. FLEISS J.P. - Statistical methods for rates and proportions. Wiley Interscience, 1973.

Si un avantage global ne peut être démontré, un bénéfice pourrait être retrouvé dans certains sous-groupes. Deux sous-groupes sont souvent méconnus par la radiologie à savoir les lésions muqueuses aiguës et les varices oesophagiennes. La proportion de lésions muqueuses aiguës semblent varier considérablement et aucune explication claire n'existe pour justifier la prévalence élevée à Glasgow en Ecosse et à New York ou Detroit aux U.S.A., par rapport à des taux nettement moindres à Aberdeen (Ecosse) et aux U.S.A. (Portland et Houston). Si certaines lésions superficielles, particulièrement lorsqu'elles sont généralisées, saignent abondamment, la grande majorité d'entre elles se résorbent spontanément et ne présentent pas de danger potentiel ultérieur. Qu'elles soient diagnostiquées objectivement ou que leur existence 
soit envisagée sur base de radiographies négatives, revet finalement peu d'importance.

Si les varices asophagiennes peuvent être décelées par la radiographie, la précision diagnostique de l'endoscopie est supérieure et cette dernière offre l'avantage important de pouvoir distinguer un saignement provenant de varices ou de lésions associées, le traitement de chaque lésion différant de façon radicale. Dans les régions où la cirrhose hépatique est fréquente l'endoscopie peut donc offrir un avantage dans le traitement de l'hématémèse et du melaena, encore que le gain ne soit pas clair.

La mortalité par ulcère chronique hémorragique est élevée chez les patients âgés : un quart des patients de plus de 70 ans décèdent. L'examen de cette mortalité suggère que les décès peuvent être divisés en 3 grands groupes: a) celui dans lequel les affections associées, comme la décompensation cardiaque ou le cancer du poumon, ont empêché un traitement actif, b) les décès post-opératoires, souvent consécutifs à des complications comme la pneumonie ou des affections cardio-vasculaires, et c) quelques décès dus à un saignement persistant.

L'expérience suggère qu'une attitude chirurgicale précoce est bénéfique; il n'y a pas d'essais contrôlés en ce domaine et on peut tout autant affirmer qu'une politique chirurgicale aggressive précoce substitue aux décès par hémorragies les issues fatales post-opératoires. La comparaison entre les résultats obtenus dans nos hôpitaux, l'un ayant une attitude plus interventioniste que l'autre pour des hémorragies de même importance, n'a montré aucun bénéfice en termes de réduction des taux de mortalité. Dans ces mêmes hôpitaux, au cours d'une période de 5 ans, les taux d'intervention pour hémorragie sur ulcère gastrique ou duodénal sont passés de $1 / 3$ à $1 / 5$, sans modifications des taux de mortalité.

Dès lors qu'une intervention précoce doit être évitée, deux problèmes demeurent:

1. Existe-t-il des moyens efficaces susceptibles d'éviter une hémorragie persistante?

2. Le risque de récidive hémorragique est-il à ce point élevé qu'une prophylaxie s'avère nécessaire?

Différents procédés d'interruption de l'hémorragie ont été imaginés. Jusqu'à présent les moyens médicamenteux n'ont pas montré d'effet convainquant. La cimétidine ne semble pas présenter d'avantages spécifiques; et d'autre part si les antifibrinolytiques semblaient prometteurs, on attend confirmation de leur intérêt.

Les méthodes endoscopiques incluent l'emploi de colles au cyanoacrylate, l'électrocoagulation, et l'application du laser. La démonstration pratique de leur valeur n'est pas encore à la mesure des résultats espérés.

Cette constatation ne reflète sans doute pas leur absence de valeur mais plutôt la difficulté de démontrer des modifications significatives au départ d'évaluations individuelles de succès ou d'échec.

Les indices de mesures choisis incluent logiquement les variations des taux de mortalité, les pourcentages d'interventions et les quantités de sang transfusé.

Si le taux de mortalité est choisi comme indicateur primaire, l'expérimentateur se heurte à la difficulté de mettre en évidence l'abaissement d'un taux de mortalité déjà faible.

Dans l'ensemble la mortalité associée à l'hématèse et au melaena est environ de $10 \%$.

Pour diminuer de moitié cette mortalité, succès remarquable, un grand nombre de patients serait nécessaire pour détecter une telle amélioration. Le tableau 1 A montre l'ordre de grandeur des échantillons requis dans les groupes de contrôle et traités si l'on désire mettre en évidence un abaissement des taux de mortalité de $10 \%$ à $5 \%$, et de $15 \%$ à $5 \%$.

Un niveau modéré de signification statistique nécessite de grandes séries, d'importance excessive par rapport au pouvoir du test, c'est-à-dire ses chances de détecter une différence si celle-ci existe réellement. Ainsi, pour espérer 4 chances sur 5 de détecter une diminution de moitié de la mortalité de $10 \%$ à $5 \%$, plus d'un millier de cas sont nécessaires; et pour une chance sur deux de montrer un abaissement de moitié, plus de 500 cas étudiés sont encore requis. Dans un tel contexte, l'expérimentateur se trouve dans une position plus difficile que le cardiologue lorsqu'il évalue les médications efficaces dans l'infarctus du myocarde, affection dont la mortalité initiale est d'environ $20 \%$; déjà dans ce domaine il est bien connu que l'on rencontre 
des difficultés considérables pour obtenir des résultats valables.

Se concentrer sur un sous-groupe d'individus, par exemple les ulcères gastriques dont la mortalité est plus élevée, donne plus de chance de succès mais présente le désavantage de limiter l'essai à un nombre plus réduit de patients et d'allonger d'autant le temps nécessaire à l'achèvement de l'étude.

TABLEAU 1

NOMBRE DE PATIENTS NECCESSAIRES POUR DÉTECTER UN CHANGEMENT DE TAUX

DE REPONSES POUR UN DEGRE DONNE

DE SIGNIFICATION ET POUR UN POUVOIR DISCRIMINATOIRE DONNÉ

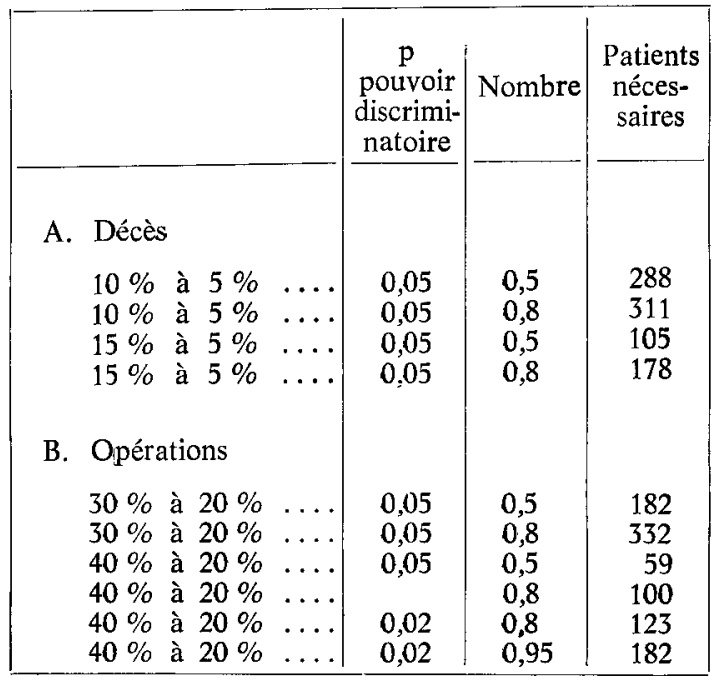

Le recours à l'intervention est un autre indice possible mais les indications opératoires sont plutôt basées sur le geste utile que sur des données bien codifiées. Les taux d'interventions pour hémorragies varient de $1 / 5$ à $1 / 3$ des malades dans les ulcères gastriques et duodénaux. Si des critères clairs pouvaient être établis, la réduction des taux d'interventions pourraient constituer un indice utile. Cependant, la diminution de l'échantillon de patients nécessaires reste encore élevée. Ainsi le tableau $1 \mathrm{~B}$ montre que pour mettre en évidence de façon valable (19 fois sur 20), une chute des taux opératoires de $40 \%$ à $20 \%$ avec un taux de signification de 0,02, 360 patients seraient nécessaires.

Un autre critère d'appréciation serait les besoins en transfusion. Ceci reflète d'une part la sévérité de la perte de sang avant le traitement, d'autre part, le jugement du clinicien susceptible de différer la réponse aux besoins réels. C'est probablement le critère le plus faible de tous, bien qu'il exprime exactement une valeur mesurable.

En raison de ces diverses difficultés, il n'est pas surprenant de voir peu d'essais cliniques relatifs à l'hématémèse et au melaena réalisés avec succès et de constater que la majorité des données concerne de petites séries procurant des résultats sans conclusion possible.

De pareils résultats serait refusés dans l'évaluation de la prévention secondaire de l'infarctus du myocarde et l'on est en droit de se demander pourquoi ils seraient pris en considération dans l'évaluation du traitement de l'hématémèse et du melaena. 